\title{
Use of Instructional Materials and Educational Performance of Students in Integrated Science (A Case Study of Unity Schools in Jalingo,Taraba state, Nigeria)
}

\author{
Mbah Modesta Ifeoma \\ National Teachers'institute, Kaduna,Nigeria.
}

\begin{abstract}
This study examined the use of instructional materials and educational performance of students in Intergrated science in unity schools in Jalingo, Taraba state.The population consisted of 249 students in the junior section of Federal science and Technical college Jalingo. The researcher and one other teacher in the school used experimental design of the pre-test and post test sessions. The post-tests mean scores were compared using a Z-test statistical analysis.Findings revealed a statistical significant difference in the mean scores.
\end{abstract}

Key Words: Instructional materials, educational performance,Intergrated science,Unity schools

\subsection{Background of the study}

\section{Introduction}

Science is the bedrock of technological development. [1] defined science as a dynamic human activity concerned with understanding the working of our world today. Countries all over the world are striving to improve their technological know-how and this can only be achieved through a solid foundation in science and technology studies. Having a solid foundation in sciences entails making students have keen interest in science (by extension Integrated Science) right from their Junior Secondary School level of education.

Many research findings have shown that Secondary School Students exhibit dwindling interest in science subjects [2]. [3] cited by [4] reported that researches on the reasons for the lack of interest in science among students included: lack of qualified teachers, lack of practical works, insufficient allotment of time for Integrated Science on the school time-table and poor method of teaching, non/poor use of instructional materials etc. These he maintained were among the major factors militating the successful implementation of the core curriculum in Integrated Science. For a start, there was therefore, the need to investigate the effects of the use of instructional materials on students' performance in Integrated Science. Thus, this work was designed specifically to unveil the effects of use of instructional materials on students educational performance in Integrated Science.

\subsection{Purpose of the study}

Specifically, this study sought to find out the effects of the use of instructional materials on the educational performance of Junior Secondary School Students in Unity Schools in Jalingo, Taraba State.

\subsection{Statement of the purpose}

This study tried to determine the extent to which the use of instructional materials influences educational performance of students in Integrated Science.

\subsection{Significance of the study}

This study:

i. Determined, for the first time, the extent to which the use of instructional materials effects students' performance in Integrated Science.

ii. The suggestions that emanated from the result of its findings would help both teachers and students in the processes of teaching and learning Integrated Science.

iii. Also, the suggestions emanating from the result of its findings, if adequately implemented would help government in policy planning, science curriculum development and implementation.

\subsection{Limitation of the study}

At the course of this study, the researcher was faced with the following constraints:

i. $\quad$ Finance - The cost of going on the internet to get information as well as the cost of producing improvised workbook for all the Junior Secondary School Students in F.S.T.C was not very easy since the researcher is only a part-time teacher. 
ii. Time Frame - This research work involved students. And it is also a requirement for the award of Post Graduate Diploma in Education. Thus, the researcher needed to be fast enough to be able to finish it within the academic session of the programme she is pursuing.

iii. Cooperation from students - Some students were very lazy to use the workbook provided as one of the instructional materials for the research.

\subsection{Delimitation}

There are three Unity Schools in Taraba State. The researcher used the JSS Students in the Federal Science and Technical College (F.S.T.C) Jalingo as a case study. The study was conducted from September 2012 to March, 2013.

\subsection{Research hypothesis}

$\mathrm{Ho}_{1}$ : There is no significant difference between the mean scores of students after being taught with instructional materials and without instructional materials.

$\mathrm{Ho}_{2}$ : There is no significant difference in the mean score of female students in experimental and control sessions.

$\mathrm{Ho}_{3}$ : There is no significant difference in the performance of male students after they are being taught with the use of instructional materials and without the use of instructional materials.

$\mathrm{Ho}_{4}$ : There is no significant difference in the mean score of experimental and control sessions of students of "13 years and above".

$\mathrm{Ho}_{5}$ : There is no significant difference in the mean score of experimental and control sessions of students of "less than 13 years".

\subsection{Operational definition of terms}

The following terms were used in this study to mean:

i. Instructional Materials - All materials including instruments and resources that aid the teacher in realizing his/her objectives in the teaching-learning process. These include textbooks, charts, improvised workbook etc.

ii. Students' Performance - This is educational achievements of students in tests and/or examinations

\subsection{Research design}

\section{Methodology}

The research design was experimental. The pretest-post test were carried out and the mean scores of the tests were contrasted to test each of the hypothesis.

\subsection{Area of study}

FSTC Jalingo is one of the unity schools in Taraba State. Just like every other unity school, it accommodates teachers and students from all states of the federation. It is a mix school where students of both sexes are given level ground to develop/prove their worth in their quest for knowledge.

Jalingo is the headquarter of Jalingo Local Government Area ((L.G.A) and also the capital of Taraba

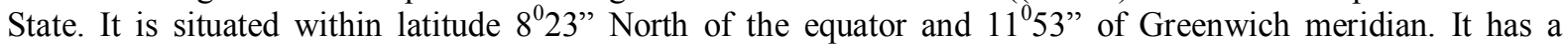
landmass of $3,871 \mathrm{sqkm}$ with an estimated population of 118,000 people. Just like every other major town in Nigeria, Jalingo has all the features of a cosmopolitan city.

\subsection{Population for the study}

This study was carried out in FSTC Jalingo using two JSS Classes A and B in each arm (J.S.S. 1 to J.S.S. 3) of the junior section of the school and the students in these classes were the main population for the study.

\subsection{Research instrument and instrumentation}

The instruments used in the study were researcher prepared pretest and post test. administered.

These tests scores projected the performances of students in the pre-test and post test that were

\subsection{Validation of research instrument}

The tests that were administered were drawn directly from the content of the lessons taught.. The tests were scored in percentage. Then, the mean and the standard deviation of each of the tests and also the Z-test were calculated. 


\subsection{1 content validity}

The tests were placed side by side with the content of the lessons that were delivered to ensure that the items fell within the scope of the contents that have been selected for the purpose of the study.

\subsubsection{Face validity}

All words and items that would otherwise confuse the students were eliminated. The questions were well numbered and each option clearly written and separated from the other(s).

\subsection{Method of data analysis}

The mean, standard deviation and the z-test were calculated and used in testing the hypotheses. The level of significance adopted form the basis for rejecting or not rejecting each of the hypotheses.

III. Result And Analysis

Table 1: $\quad$ Pre-test and post test mean scores of students in Integrated Science in Junior Secondary School Section of Federal Science and Technical College, Jalingo, Taraba State.

$\begin{array}{llrr}\text { Class } & \text { Pre-test } & \text { Experimental } & \text { Control } \\ \text { J.S. } 3 & 60.61 & 66.22 & 64.00 \\ \text { J.S. 2 } & 59.68 & 65.68 & 57.88 \\ \text { J.S. 1 } & 58.92 & 72.19 & 56.95 \\ \text { average } & 59.62 & 68.33 & 63.16\end{array}$

Table 2: $\quad$ Result of z-test analysis to determine if there is a statistically significant difference in the mean scores of the experimental and control sessions.

$\begin{array}{lcllrl}\text { Session/Mean score } & \text { Pre-test } & \text { Post-Test } & \text { Mean gain } & \text { Standard Error } & \text { Z-value } \\ \text { Experimental } & 59.62 & 68.33 & 8.71 & 1.4676 & 0.4998 \\ \text { Control } & 59.62 & 63.16 & 3.54 & & \end{array}$

Table 3: $\quad$ Result of $z$-test statistical analysis to determine if there is significant difference in the scores of experimental and control sessions of female students.

$\begin{array}{llrccc}\text { Session/Mean score } & \text { Pre-test } & \text { Post-Test } & \text { Mean gain } & \text { Standard Error } & \text { Z-value } \\ \text { Experimental } & 54.51 & 68.57 & 13.96 & 2.8629 & 0.4998 \\ \text { Control } & 54.51 & 58.52 & 4.01 & & \end{array}$

Table 4: $\quad$ Result of $z$-test statistical analysis to determine if there is significant difference in the mean

\begin{tabular}{|c|c|c|c|c|c|}
\hline Session/Mean score & Pre-test & Post-Test & Mean gain & Standard Error & Z-value \\
\hline Experimental & 56.70 & 67.13 & 10.43 & \multirow[b]{2}{*}{2.9990} & \multirow[b]{2}{*}{0.4666} \\
\hline Control & 56.70 & 61.63 & 4.93 & & \\
\hline
\end{tabular}

Table 5: Result of z-test statistical analysis to determine if there is significant difference in the mean scores of students of 13 years and below.

$\begin{array}{lccccc}\text { Session/Mean score } & \text { Pre-test } & \text { Post-Test } & \text { Mean gain } & \text { Standard Error } & \text { Z-value } \\ \text { Experimental } & 56.42 & 68.36 & 11.94 & & \\ & & & & 2.9490 & 0.4987 \\ \text { Control } & 56.42 & 59.42 & 3.00 & & \end{array}$

Table 6: $\quad$ Result of $z$-test statistical analysis to determine if there is significant difference in the mean scores of students of above 13 years.

\begin{tabular}{lcccccccc} 
Session/Mean score & Pre-test & Post-Test & Mean gain & \multicolumn{2}{l}{ Standard Error } & Z-value \\
Experimental & 58.07 & & 66.31 & & 8.24 & 2.6374 & 0.4763 & \\
Control & & 58.07 & & 61.08 & & 3.01 & &
\end{tabular}

In the study to find if any difference existed in the academic performance of the pupils taught with instructional materials and those taught without the use of instructional materials. Also, a z-test statistical analysis was employed to determine if the difference observed is the mean scores considered were statistically significant. 
TABLE I shows an obvious difference in the mean scores of pupils taught with the use of instructional materials. The mean scores of the students when taught with the use of instructional materials and without the use of instructional materials were 68.33 and 63.16 respectively.

TABLE II shows the result of the z-test statistical analysis to test null hypothesis one $\left(\mathrm{Ho}_{1}\right)$ earlier stated. A z-value of 0.4998 was obtained at 0.05 level of significance. The hypothesis was therefore rejected because a statistically significant difference had been found in the mean scores of students taught with the use of instructional materials and without the use of instructional materials.

TABLE 3 shows the mean scores of female students before and after treatment. The mean gain in the experimental session was higher. And also there was statistical significance difference in the mean scores of students after they were taught with and without the use of instructional materials because a z-value of 0.4998 was obtained at 0.05 level of significance. Thus null hypothesis two $\left(\mathrm{Ho}_{2}\right)$ was rejected.

TABLE 4 reveals a mean gain of 10.43 percent and 4.93 percent in experimental session and control session of male students. At probability level of 0.05 , a z-value of 0.4666 was obtained. Giving a statistical significance difference. Thus, the null hypothesis three $\left(\mathrm{Ho}_{3}\right)$ was rejected.

TABLE 5 shows that there was a remarkable mean gain in the post test scores of the experimental session when compared to the control. Also, at 0.05 level of significance $\mathrm{z}$-value of 0.4987 was obtained. This shows that there was statistical significance difference between the mean scores of experimental and control session of students of $\geq 13$ years. Thus, hypothesis four $\left(\mathrm{Ho}_{4}\right)$ was rejected.

TABLE 6 reveals a mean gain of 8.24 percent and 3.01 percent in the experimental and control sessions of students of above 13 years. Also, at 0.05 level of significance, a z-value of 0.4763 was obtained. This showed that there was a statistical significance difference in the mean scores of the experimental and session group. Therefore, the null hypothesis five $\left(\mathrm{Ho}_{5}\right)$ was rejected.

\section{Discussion}

The study clearly reveals that the use of instructional materials such as workbooks improved the quality of learning in the students. This agrees with the findings of [20] who also observed that teachers work more effectively when they use instructional materials. He also stated that the use of instructional materials provide an enriched classroom atmosphere. Also, [21] observed that where students engaged in the processes of science in their schools, the level of achievement in science was higher.

It was also found that both male and female students perform better when they are taught with instructional materials.

This study also observed that students of different age groups also perform better when they are taught with instructional materials. Instructional materials stimulates the various senses of the body. And thus, help students to learn better.

\section{Conclusion}

It is obvious from the findings of this study that there is statistical significant difference in the educational performance of students when they are taught with instructional materials than when they are not taught with them.

\section{Recommendations}

Based on the finding from this study, the following are recommended:

1. Teachers should develop a positive attitude towards the use of instructional materials.

2. The time table planners should allocate enough time or more periods for teaching Integrated Science so that both teachers and students would have enough time for maximum utilization of the instructional materials.

3. The government through it's agencies, should assist schools by supplying instructional materials to them.

4. Teachers also should try and improvise instructional materials where the standard ones are not available.

5. School management should ensure that every student has the prescribed text book (Integrated Science text book) along side with the work book.

6. School management should also assist teachers who wish to improvise instructional materials by way of supplementing the cost, if not sponsoring it.

[1] Ogunleye, B.O. (2002). Towards the Optimal Utilisation and Management of Resources for the Effective Teaching and Learning of Physics in Schools. Proceedings of the $41^{\text {st }}$ Annual Conference of the Science Teachers' Association of Nigeria. University of Lagos, Nigeria PP. $215-220$.

[2] Esiobu, G.O. (2005), Development Genre Issues in Science and Technology Education for Development. NERDC Press, Lagos PP: $137-156$

[3] Afuwape M.O. and olatoye R.A. (2004). Students Integrated Science Achievement as a Predicator of later Achievement in Biology, Chemistry and Physics. Journal of Science Teachers' Association of Nigeria. 39(12): 11-16. 
[4] Oludipe D.I. (2011). Developing Nigerian Integrated Science Curriculum. Journal of Soil Science and Environmental Bolanle, T.D. (no date). The Influence of Teacher Preparation and Use of Instructional Materials on Primary School Pupils' Performance in Integrated Science (NP). Management 2(8): 134- 145.

[5] Onasanya S.A. and Omosewo E.O. (2011). Effect of Improvised and Standard Instructional Materials on Students Academic Performance in Physics in Ilorin, Nigeria. Singapore Journal of Scientific Research.5(3)123-127

[6] Peril and promise (2000). 'Higher Education in Developing Countries'. The Taskforce on Higher Education and Society. 1818 H Street, N.W. Washington, D.C. 20433, U.S.A PP: $71-72,82$.

[7] Musa K.W, Andrawus A.B. and Riki F.A. (2010).

[8] The Essentials of Teaching and Learning Process. Jos University Press Ltd P. 58.

[9] Egunjobi S.Olude A.O,Zubairu S.,Mu'azu G.(2005).General Methods inEducation(PDE103).NTI Press.

[10] Uga O. (1996). Curriculum Development for Africa. Africana - Fep Publishers Limited.

[11] Murphy G. (1968). An Introduction to Psychology $2^{\text {nd }}$ Indian Reprint, New Delhi Oxford and IBH.

[12] Mangal S.K. and Mangal U. (2010). Essential of Educational Technology. PHI Learning Private Limited New Delhi - 110001 PP: $45-172$.

[13] Clark S.C.T. (1970). 'General Teaching Theory'.Journal of Teacher Education. 21(3): 9 - 11.

[14] Smith H.P. (1961) Psychology in Teaching. New York Prentice Hall.

[15] Abdullahi, A. 1982. Science Teaching in Nigeria. Ilorin Atoto Press.

[16] Agina-Obu, T.N. (2005). Theories are Practice of Teaching, Port Harcourt; Harey Publication.

[17] Mishra R.C. (2007). APH Publishing Corporation 4435 - 36/7, ANSARI ROAD, DARYAGANI. New Delhi - 110002, PP 169189.

[18] Muyibul H.S. (2008). Challenges of Educational Technology APH Publishing Corporation Ansari Road, Darya Ganj. New Delhi110002 , PP $15-17$.

[19] Sigel, I. and Cocking, R. (1977). Cognitive Development from Childhood to Adolescence. A Constructivist Perspective. N.Y: Holt, Richart and Wiston.

[20] Davies, J. (1972). An assessment of changes in science facilities initiated by NDEA. Title funds used for high school science in Tennessee between 1965 - 1970. Unpublished Ph.D thesis, University of Tennessee (University Microfilms, 73 - 2439).

[21] Comber, L.C and Reeves, P.J. (1973). Science Education in Nineteen Centuries. New York: John Wiley and Sons. 